\title{
Acute toxicity study of Retinoic acid in the freshwater eel, Monopterus cuchia.
}

\author{
B. Mech and A.K Rai \\ Department of Life Sciences, Dibrugarh University, Dibrugarh-786004
}

\begin{abstract}
All-trans retinoic acid (RA) is an active metabolite of vitamin A and its administration may prevent most of the defects generated by vitamin A deficient. Vitamin A plays an important role in many essential biological processes. The present study was carried out to calculate the $L D_{50}$ value of $R A$ in Monopterus cuchia through intramuscular injection. Statistical analysis was done using probit analysis by SPSS software. Six doses were selected and the fishes were sampled prior to injection (day 0) and days 1, 2, 3 and 4 after injection. The calculated value can be assumed to be used in various purposes such as in fish farming, in aquaculture etc as fishes are susceptible to various wounds, infection and diseases due to various environmental factors, pollution and many other reasons. As a result the impact of RA may be used in managing various fish farms and to increase the immune function of the fish for better yield.
\end{abstract}

Key words: $R A, L D_{50}$, fish farms.

\section{Introduction}

The Retinoids are a class of chemical compounds that are related chemically to Vitamin A. Retinoic acid (RA), a low molecular weight lipophilic metabolite of Vitamin A or retinol, is the most potent natural retinoid able to influence biological processes such as vision, tissue maintenance, embryonic development, cell growth, differentiation of various epithelia in the body, exert immunomodulatory action and alter cellular adhesiveness (Zile, 1998; Vahlquist et al., 2008; Axel et al., 2001; Orlandi et al., 2003; Liu et al., 2012. RA is a naturally occurring metabolite of retinol, was the first retinoid snythesized. The molecular formula of RA is $\mathrm{C}_{20} \mathrm{H}_{28} \mathrm{O}_{2}$ with molecular weight of 300.4 and melting point $180-182^{\circ} \mathrm{C}$ (Vahlquist et al., 2008; Martindale, 1993). RA has a complex pleiotropic function during vertebrate patterning, development and can induce regeneration in a number of different organ systems (Blomhoff, 1994).

Acute toxicity of a metabolite can be determined by the calculation of $\mathrm{LD}_{50}$, i.e. the dose that will kill $50 \%$ of animals of a particular species. The $\mathrm{LD}_{50}$ is one way to measure the short term poisoning potential of a metabolite. The toxicity study is essential to find out toxicants limit \& safe concentration, so that there will be minimum harm to aquatic fauna in the near future. Various investigations are made regarding the effect of RA in fin regeneration processes, development, cell signaling, tolerance \& immunity \& in patterning events in early neuronal development in fishes. (Holder \& Hill, 1991; Geraudie et al., 1993, 1994, 1995; White et al., 1994; Browman \& Hawryshyn, 1994; Armstrong et al., 1994; Ferretti \& Geraudie, 1995; Miwa \& Yamano, 1999; Sternberg \& Moav, 1999; Haga et al., 2002; Muehlberger et al., 2005; Naqashima et al., 2009; Fernandez \& Gisbert, 2011; Pittlik \& Begemann, 2012; Blum \& Begemann, 2012 ). The present study has been focused to evaluate the acute toxic effect of RA on mud eel, Monopterus cuchia which is a good experimental animal with great tolerance and survivability.

\section{Materials and Methods}

Live specimens of Monopterus cuchia were collected from local fish market at Dibrugarh, Assam, India. The fishes were kept in plastic aquaria and fed with small dead fishes procured from market. The fishes were allowed to acclimatize to laboratory condition for one week. Water was aerated twice a day to prevent hypoxic condition.

\section{a. Preparation of RA stock solution:}

A $30 \mathrm{mg} / \mathrm{ml}(\mathrm{w} / \mathrm{v})$ stock solution of RA (Sigma Aldrich) was prepared in DMSO immediately before use.

\section{b. Acute toxicity test:}

$\mathrm{LD}_{50}$ can be initially determined as a pilot study by a so called 'staircase method' using a small number of fishes ( 4 each dose) and increasing the doses of RA. The chosen range of doses was such that it resulted in 0 to $100 \%$ mortality. Acute toxicity tests were conducted over $96 \mathrm{~h}$ (4 days).For each experiment, Monopterus cuchia of approximate $1 \pm 98 \mathrm{~g}$ was selected. Fishes were cold anaesthetized following (Mittal \& Whitear, 1978) 
before the experiments begin. Six doses of $0,50,100,150,250,400 \mu \mathrm{g}$ RA/ $\mathrm{g}$ fish were injected intramuscularly to six groups of fishes, four in each group.

The fishes were observed for first $2 \mathrm{~h}$ and then at $6 \mathrm{~h}$ and $24 \mathrm{~h}$ for any toxic symptoms. After $24 \mathrm{~h}$, the number of deceased fishes was counted in each group and percentage of mortality calculated. The resulting mortality was noted in the range of 10 to $90 \%$ for each dose for the duration of $24,48,72 \& 96 \mathrm{~h}$. Each experiment was repeated thrice to obtain constant results.

\section{c. Statistical analysis:}

The average fish mortality data were subjected to probit analysis for calculating $\mathrm{LD}_{50}$ and other statistics at $95 \%$ confidence limits of upper confidence limits (UCL) and lower confidence limit (LCL) and ChiSquare value was calculated using SPSS $_{18.0}$ (Statistical Package of Social Sciences) software. Results with $\mathrm{p}<$ 0.05 were considered to be statistically significant.

\section{Results}

It was observed early in the experiment that the injected fishes exhibited altered behavior as compared to the controls. Immediately after injection of RA the fishes became restless and started moving to and fro in the water. Then they started coming to the surface of the water to inhale air and it looked as though they were suffocating. Irregular erratic and sometimes jerky movements were observed in fishes exposed to different doses of RA. The opercular movement increased initially just after RA was injected but after $1 \mathrm{~h}$ it became normal. The fishes injected with the highest dose showed a change in the skin with the formation of white patches throughout the body of the fish. The fishes died before $72 \mathrm{~h}$.But the fishes injected with lower dose did not show any morphological change. The percentage mortality of the mud eel, Monopterus cuchia during the exposure of the metabolite RA at different doses is shown in table 1.

Table 1: Results of the lethal doses of RA for the determination of $\mathrm{LD}_{50}$ after intramuscular injection in Monopterus cuchia.

\begin{tabular}{|l|l|l|l|l|}
\hline Group & Dose $(\mu \mathrm{g} / \mathrm{g})$ & Log dose & \% dead & Probits \\
\hline 1 & 0 & 0 & 0 & 0 \\
\hline 2 & 50 & 1.699 & 25 & 0.236 \\
\hline 3 & 100 & 2.000 & 50 & 0.521 \\
\hline 4 & 150 & 2.176 & 75 & 0.693 \\
\hline 5 & 250 & 2.398 & 75 & 0.859 \\
\hline 6 & 400 & 2.602 & 100 & 0.945 \\
\hline
\end{tabular}

Table 2. Statistical calculation of acute toxicity effect of RA in Monopterus cuchia.

\begin{tabular}{|l|l|l|l|l|}
\hline $\begin{array}{l}\text { Chi-square } \\
\text { value }\end{array}$ & Regression equation & $95 \%$ confidence limit for log(conc. of RA) & LD $D_{50}$ value $(\mu \mathrm{g} / \mathrm{g})$ \\
\cline { 3 - 4 } & & Lower bound & Upper bound & \\
\hline 0.695 & $\mathrm{Y}=-1.09296+.801729 \mathrm{X}$ & 0.823 & 2.264 & 97.02 \\
\hline
\end{tabular}

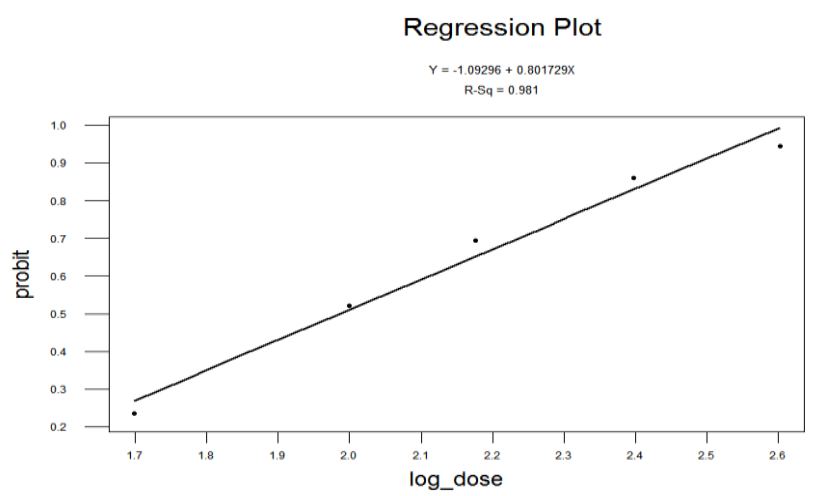

Fig.1. Plot of log_dose versus probits for calculation of LD50 of RA.

The $\mathrm{LD}_{50}$ value and mortality showed a direct relationship. The regression equation, Chi Square, $95 \%$ confidence limit and lethal dose are show in table 2 . The $\mathrm{LD}_{50}$ value obtained for $\mathrm{RA}$ is $97.02 \mu \mathrm{g} / \mathrm{g}$ of fish Monopterus cuchia.

\section{Discussion}

There is an optimal dose for vitamins for each and every species. A deficiency of it may lead to malfunctioning and deformities. RA is the oxidized form of vitamin A alcohol and has some vitamin A 
activity. The evaluation of $\mathrm{LD}_{50}$ dose of the metabolite $\mathrm{RA}$ is an important step before carrying out further studies on physiological changes in animals. In the present experiment, the lethal dose of RA for Monopterus cuchia was calculated. The acute toxicity level was expressed in terms of $\mathrm{LD}_{50}$ values. The $\mathrm{LD}_{50}$ was found to be $97.02 \mu \mathrm{g} / \mathrm{g}$ of fish at $96 \mathrm{~h}$. The percent mortality rate of fish increases with increase in dose value. In the present probe, acute toxicity test shows that the effects of RA are dose related.

The nutritional requirements for biological defence against chemical toxicity include vitamins. The role of nutrition in detoxification is essential to survival (Parke, 1991). Blazer, 1992 reported that diseases resistance in fish encompases a variety of mechanisms including maintenance of epithelial barriers and the mucus coat, non specific cellular factors such as phagocytosis by macrophages and neutrophils, non specific humoral factors such as lysozyme, complement and transferrin. Numerous nutritional factors can significantly affect incidence and severity of a variety of infectious diseases. Individual micronutrients known to affect disease resistence include vitamin $\mathrm{A}, \mathrm{B}_{6}, \mathrm{C} \& \mathrm{E}$ and the minerals iron and fluoride. The potential for dietary enhancement of disease resistance in fish culture certainly exists. Geraudie et al., 1994 analysed that depending on the concentration and the experimental schedule, RA can have both tetragonic and morphogenetic effects on the regenerating fin of zebrfish. Browman \& Hawryshyn, 1994 established that RA modulates retinal development in the juveniles of a Teleost fish. Sternberg \& Moav, 1999 studied that in carp (Cyprinus carpio) pituitary cells have shown that addition of T3 \& RA increase the steady state levels of the GH messenger RNA. Blum \& Begemann, 2012 developed an RA regime that does not induce cell death, rather it demonstrably enhances RA signaling and positively influences fin regeneration.

Ed Devlin's from Biology Department at Hampden Sydney College studied by exposing the zebrafish embryos to a gradual series of RA concentration for time period of 72 to $96 \mathrm{hs}$. At elevated concentration of RA a number of characteristics malformations were recorded. A team of researchers from the University of Konstanz in Southern Germany claim that RA played a part in the tropical freshwater fish's ability to rebuild its fin. They found that the fish uses a special genetic trick that allows the RA to control the formation of blastema, which means the animal is able to produce a store of cells that can rebuilt the fin.

As RA has immense advantages among fishes, there is an urge to establish a lethal dose of RA for fishes. The present study was an attempt to establish the in vivo use of RA in fish and the calculated value can be assumed to be used in various purposes such as in fish farming, in aquaculture etc as fishes are susceptible to various wounds, infection and diseases due to various environmental factors, pollution and various other reasons. As a result the impact of RA may be used in managing various fish farms and to increase the immune function of the fishes for better yield.

\section{Acknowledgment}

Authors are thankful to the Head of the Department of Life Sciences, Dibrugarh University for providing the necessary laboratory facilities. The authors are also grateful to the Department of Science and Technology, New Delhi, India for financial grant ( INSPIRE Fellowship ).

\section{References}

[1]. Armstrong, N. M., McCaffery, P., Gilbert, W., Dowling, J. E. and Drager, U.C. 1994. Retinoic acid is necessary for development of the ventral retina in zebrafish. Proc. Natl. Acad. Sci. USA, 91: 7286-7290.

[2]. Axel, D. I., A. Friggea, J . Dittmanna, H . Rungea, L. Spyridopoulosa, R. Riessen, R. Viebahn, and K. R. Karsch. 2001.All trans retinoic acid regulates proliferation, migration, differentiation and extracellular matrix turnover of human arterial smooth muscle cells. Cardiovascular Research 49: 851-862.

[3]. Blum, N. \& Begemann, G. 2012. Retinoic acid signaling controls the formation, proliferation and survival of the blastema during adult zebrafish fin regeneration. Development, 139: 107-116.

[4]. Browman, H. I. \& Hawryshyn, C. W. 1994. Retinoic acid modulates retinal development in the juveniles of a teleost fish. Journal of experimental Biology, 193: 191-207.

[5]. Blazer, V. S. 1992. Nutrition and disease resistance in fish. Annual Reviews of Fih Diseases, 2: 309-323.

[6]. Geraudie, J., Brulfert, A., Mannot, M. J., Ferretti, P. 1994. Teratogenic \& morphocenetic effect of retinoic acid on the regenerating pectoral fin in zebrafish. J. Exp. Zool., 269, 1: 12-22.

[7]. Blomhoff, R. ed. (1994).Vitamin A in health and disease. Basic science and clinical aspects. New York: Marcel Dekkar Ltd.

[8]. Fernandez, I. and Gisbert, E. (2011). The effects of vitamin A on flatfish development and skeletogenesis: A review, J. aquaculture, 315, 1-2:34-48.

[9]. Ferretti, P. and Geraudie, J. (1995) Retinoic acid-induced cell death in the wound epidermis of regenerating zebrafish fins. Dev.Dyn. 202(3): 271-283.

[10]. Geraudie, J., Brulfert, A., Monnot, M.J. and Ferretti, P. (1994). Teratogenic and morphogenetic effect of retinoic acid on the regenerating pectoral fin in zebrafish. J. Exp. Zool. 269: 12-22.

[11]. Geraudie, J., Ridet, A., Monnot, M.J., Thorogood, P. and Ferretti, P. (1993). Is exogenous retinoic acid necessary to alter positional information during regeneration of the fin is zebrafish? Prog. Clin. Biol. Res. 383B: 803-814.

[12]. Geraudie, J., Monnot, M.J., Brulfert, A. and Ferretti, P. (1995). Caudal fin regeneration in wild type and long fin mutant zebrafish is affected by retinoic acid. Int. J. Dev. Biol. 39, 373-381.

[13]. Haga, Y., Takeuchi, T. and Seikai, T. (2002). Influence of all-trans retinoic acid on pigmentation and skeletal formation in larval Japanese flounder. Fisheri. Scie. 68 (3): 560-570.

[14]. Holder, N. \& Hill, J. 1991. Retinoic acid modifies development of the midbrain - hindbrain border \& affects cranial ganglion formation in zebrafish embryos. Development, 113, 1159-1170. 
[15]. Liu, Z., G. Ren, C. Shanggnan, L. Guo, Z. Dong, Y. Li, W. Zhang, L. Zhao, P. Hou, Y. Zhang, X. Wang, J. Lu, and B. Huang. 2012. ATRA inhibits the proliferation of DU145 prostate cancer cells through reducing the methylation level of HOXB13 gene. PLoSONE 7: e40943.

[16]. Martndale, W. 1993. In the Extra pharmacopoeia, 30 $30^{\text {th }}$ ed, ed. J.E.F. Reynolds, 770. London. Pharmaceutical Press.

[17]. Mittal, A. K. \& Whitear, M.(1978).A note on cold anaesthesia of poikilotherms.J. Fish Biol. 13, 519-520.

[18]. Miwa, S. and Yamano, K. (1999). Retinoic acid stimulates development of Adult-type Chromatophores in the Flounder. J. Exp. Zool, 284: 317-324

[19]. Muehlberger, T., Moresi, J.M., Schwarze, H., Hristopoulos, G., Laenger, F. and Wong, L. (2005). The effect of topical tretinsin on tissue strength and skin components in a murine incisional wound model. J. An. Acad. Dermatol. 52 (4): 583-8

[20]. Naqashima, M., Sakurai, H., Mawatari, K., Koriyama, Y., Matsukawa, T. and Kato, S. (2009). Involvement of retinoic acid signaling in goldfish optic nerve regeneration .Neurochem. Int. 54 (3-4): 229-36.

[21]. Orlandi, M., B. Mantovani, K. Ammar, E. Avitabil, P. D. Monte, and G. Bartolinia 2003. Retinoids \& Cancer; Antitumoral effects of ATRA, 9 cis RA \& the new retinoid IIF on the HL-60 leukemic cell line. Medical Principles \& Practice 12: 164-169.

[22]. Pittlik, S. and Begemann, G. (2012). New sources of Retinoic acid synthesis revealed by live imaging of an Aldh1a2- GFP reporter fusion protein throughout zebrafish development. Developmental Dynamics. 241, 7, $1205-16$.

[23]. Parke, D. V. (1991). Nutritional requirements for detoxication of environmental chemicals.Food additives \& Contaminants. 8,3: 381-396.

[24]. Sternberg, H. \& Moav, B. (1999). Regulation of the growth hormone gene by fish thyroid/ retinoid receptors. Fish Physiology \& Biochemistry. 20: 331-339.

[25]. Vahlquist, A., S. Kuenzli \& J. H. Saurat (2008). Retinoids (chapter 229). In Fitzpatricks dermatology in general medicine, $7^{\text {th }}$ ed, ed. K. Wolff, A. L. Goldsmith, S. I. Katz, B. A. Gilchrest, A. S. Paller, and D. Leffell. New York: McGraw-Hill.

[26]. White, J. A., Michael, B. B., Jones, B. \& Petkovich, M. (1994). A zebrafish retinoic acid receptor expressed in the regenerating caudal fin. Development, 120, 1861-1872.

[27]. Zile, M. H. (1998). Vitamin A and embryonic development. An overview. The journal of Nutrition. 128: 455S-458S. 